TURIZAM

Volume 19, Issue 2

47-55 (2015)

\title{
Employee Perceptions of HIV \& AIDS on the Hospitality Industry in Zimbabwe
}

\author{
Forbes Kabote, Freddy Hamadziripi, Sebastian Vengesayi, \\ Felisitas Chimutingiza, Theresa TMakoni*
}

Received: September 2014 | Accepted: May 2015

\begin{abstract}
HIV \& AIDS prevalence is causing lots of deaths in the hospitality industry affecting the most productive population. The study was conducted to explore employee perceptions of $H I V \mathcal{E}$ AIDS on the hospitality industry. Using qualitative research philosophy data was collected using semi-structured questionnaires from employees at selected hotel establishments. The data was analyzed thematically. Two critical themes emerged from the study. Firstly HIV \& AIDS was being treated as a taboo subject and secondly; there are no clear organizational policies on HIV $\mathcal{E}$ AIDS. The researchers concluded that hospitality organizations are still ignorant of devastating existence of HIV \& AIDS. Three recommendations were made from the study. Hospitality establishments should embrace the fact that HIV \& AIDS exist, Organizations should work with employees to produce workable policies and that organizations should take heed of government efforts in tackling HIV \& AIDS and do their part in this international cause.
\end{abstract}

Key words: HIV \& AIDS, Hospitality Industry, HIV positive employees.

\section{Introduction}

The Human Immunodeficiency Virus (HIV) and Acquired Immunodeficiency Syndrome (AIDS) are making a decided impact on business and will continue to do so (Beharie, 2010; Brungard, 1999:143). An estimated 34 million people are living with HIV in the world (UNAIDS, WHO, UNICEF, 2011). According to Jennifer (2004) nearly 30 million people worldwide have died of HIV and AIDS related causes since the first recognised case of the epidemic occurred in the United States of America in the early 1980s. Since the first cases were recorded HIV and AIDS has become synonymous with low and middle income nations with its productive population mostly affected. HIV affects the health of individuals, impacts on households, communities, organisations and economic development of nations. Due to these challenges new efforts are being made everyday to address the epidemic from household level to international community level.

* School of Hospitality and Tourism, Chinhoyi University of Technology, Private Bag 7724, Chinhoyi, Zimbabwe. Corresponding author. Email: fkabote@cut.ac.zw or kabote123@gmail.com, Phone +263772967367 
According to UNAIDS World Aids day report in 2010 Countries in Sub Saharan Africa, including Zimbabwe, South Africa and Botswana, have one of the highest HIV and AIDS prevalence rates in the world. Estimates indicate that sixty eight percent of all people are said to be infected thereby exerting increasing pressure on the public health system (UNAIDS, 2010). HIV and AIDS therefore have the potential of stagnating per capita output growth of the country in the foreseeable future making it arguably the single most serious economic challenge facing Zimbabwe today. However different sectors of the economy address the problem differently.

The tourism industry which encompasses hospitality is one of the largest in the world employing more than eight percent of global workforce (Jennifer, 2004; ILO, 2011). The hospitality industry employees are highly vulnerable to HIV/AIDS infection. This has been attributed to job mobility, nature and location of their work, time spent away from home and families and high exposure to commercial sex workers (UNICEF, 2001; Ministry of Health, 2001, Jennifer, 2004). As a result of HIV prevalence, various effects have been recorded such as illness related absenteeism, death of skilled workers, lower profits, greater difficulty in delivering quality and efficient services, higher costs of production, training, insurance cover and poor employee morale (Welbourn, 2008). These effects of HIV/AIDS have either a direct or an indirect financial implication on the hospitality organisation (Moore et al., 2006).

Over the past years Zimbabwe's hospitality industry has suffered financially or otherwise from effects of HIV/AIDS (Zengeni \& Zengeni, 2012). Lessons from South Africa (Jennifer, 2004) indicated that forty five percent of hotel companies had to deal with many diverse human resources issues as a result of the epidemic. According to UNAIDS/WHO (2005) there was an increasing difficulty in many organisations in costs of training, recruitment of unskilled and inexperienced technical, professional and managerial staff. As the level of skills and experience declines, there are knock-on effects on efficiency and productivity in the hospitality industry. Human Resources practitioners at the workplace have to grapple with ways to cope with staff that was increasingly unwell and unable to perform to standard and continue to miss productivity levels and deadlines.

Given this scenario this study sought to provide answers to the question; what are the employees' perceptions of HIV/AIDS and how such perceptions may be incorporated in the fight against the devastating effects of the pandemic on the hospitality industry of Zimbabwe?

\section{Literature review}

\section{HIVIAIDS Awareness}

HIV/AIDS awareness was the critical component in the fight against the disease. Sirvastava et al (2003) defines awareness as the state or ability to perceive, to feel or to be conscious of events, objects or sensory patterns. Various organizations are trying to create awareness about HIV infection, effects and what they are doing to help HIV victims. Pro-active role in developing responses to HIV/AIDS by top management was critical for the management of HIV/ AIDS (Yap \& Ineson, 2012; Sirvastava et al, 2003). By tackling HIV/AIDS directly and responsibly, hoteliers and restaurateurs join the business around the world in the fight against HIV/ AIDS by providing accurate information to employees and their families, as well as developing workplace policies and supportive environments. As the impact of HIV/AIDS on the workplace becomes more evident, increasing numbers of hotel businesses are providing HIV/ 
AIDS awareness, training and education programs. According to Jennifer (2004) the hospitality industry recognizes that due to lack of knowledge and understanding about HIV/AIDS some of their employees may have potentially a negative attitude about working with a person who has HIV. Through proactive HIV policies, education and awareness programmes employers are protecting their workforces from the impacts of HIV and in turn protect their businesses. Hotels are making important contributions towards national and international efforts of minimising the impacts of HIV.

\section{HIVIAIDS Epidemic and African Continent}

The African continent is the worst affected and infected with HIV/AIDS hosting 70\% of global infections (Chris, 2008). However Sub-Saharan Africa is home to the majority with $68 \%$ (about 22.5 million) infected people (WHO, 2007). A number of factors have been identified that facilitate the increase and spreading of HIV/AIDS. These includes behaviours such as casual unprotected sex, multiple partners, injecting or prohibited drug use, relations with 'high risk' categories of people such as commercial sex workers, it takes too long (8-10 years) for the first signs of infection to show, social, cultural, biological, economic factors and ineffective flow of information due to taboos and cultural norms surrounding sex (Anarfi, et al, 2007; Abbott, 2005; Oppong, 1995; Archer, 2002; Maryoga, 2001). Thus spreading of HIV in Africa remains a big challenge.

The continued spreading of HIV/AIDS presents multiple challenges to the country and hospitality industry. HIV has the potential to impede the very development of the hospitality sector and reverse some of the hard won gains made in the past (Jennifer 2004; Loewenson, 2004). Due to increased deaths of productive people productive sectors of the economy are affected as quantity and quality of skilled personnel deteriorates reducing productivity and profits whilst increasing costs (UNAIDS, 2009; AIDS Action, 2001; ILO, 2011). The hospitality industry being labour intensive is hit hard. However hope is not lost as the workplace has been identified as a good environment for HIV/AIDS prevention activities. Thus with management being increasingly concerned about the likely impact of the disease on their service delivery efforts, it remains critical to use the work environment for HIV/AIDS management, (Dossier 2007).

HIV/AIDS has varying impacts on individual companies (Wolfensohn, 2009). Some of these are declining levels of productivity; this was linked to increased absenteeism due to ill health, increased organizational disruption due to morbidity and mortality from HIV/AIDS (Grodeck, 2007). Other than declining levels of productivity companies also face increased costs; these are associated with recruitment, selection and training of new staff, insurance cover and pensions for early retirement due to ill health, health management costs, funeral costs, rising consumption costs and declining capacity deepening (Wolfensohn, 2009; Grodeck, 2007; Moore et al 2006; Lawson, 2004; Jackson 2002; Ruggles et al, 2001).

\section{HIV/AIDS and the hospitality industry}

The hospitality industry is characterised by staff mobility, staying away from home and families, risk sexual behaviour by tourists on holidays, drug and alcohol abuse by tourists and employees, prevalence of sex tourism (commercial sex) by employees and tourists (ILO, 2012; Zengeni and Zengeni, 2012; Hannum, 2004; Apostolipoulos, 1996; Ford, 1991). By its nature the hospitality industry is labour intensive and highly interactive. This characteristic continuously exposes employees to the customers which increases the risk behaviour (ILO, 2012). However 
on the other hand when employees get sick customers quickly notice and discrimination sets in (Monjok, 2009). This calls for a balanced management of HIV/AIDS issues at work.

Hospitality businesses need to understand the impact of HIV/AIDS on employees, families, communities and organizations (Chris, 2008). After which they have to take action. Various workplace strategies have been identified and these includes coming up with workplace strategies for prevention, education and possibly treatment of HIV and AIDS related infections, promotion of condom use, behaviour change and inter hotel group awareness campaigns, ensure legal compliance, design workplace HIV/AIDS programs to fit local cultures and employees to be supported in the fight against HIV/AIDS (Zengeni and Zengeni, 2012; Yap \& Ineson, 2009; Chris, 2008; Jennifer, 2004; Lawson, 2004; Sirvastava et al, 2003; Jackson, 2002). It is also critical for organizations to realize that HIV is real and come up with workplace codes that address critical issues around HIV related problems (ILO, 2010; Loewenson, 2004).

Despite the various works that has been done globally, there was only one study on HIV/ AIDS and the Tourism industry from the management point of view (Zengeni and Zengeni, 2012). However there was no study on employee perceptions of HIV/AIDS on the hospitality sector particularly in Zimbabwe at the time of writing this paper. This was despite the fact that it is one of the hardest hit by the disease as indicated in the literature. Thus the objective of the study was to explore employee perceptions of HIV \& AIDS on the hospitality industry in Zimbabwe. The results of the study will bring out insights on how to address the epidemic in the hospitality industry from the employees' perspective. They will also add to current literature on HIV/AIDS management at hospitality workplaces and influence organizational policies on HIV/AIDS management.

\section{Research methodology}

The study was based upon sixty semi structured questionnaires with hospitality industry employees. These were all general employees from various departments of six randomly selected 3 stars to 5 stars hospitality establishments in Harare, Zimbabwe's capital city. Fifteen respondents were conveniently selected from each establishment with emphasis on representation of all departments within the hotel (Valentine, 2005). After receiving back the questionnaires and cleaning the data, a total of sixty usable questionnaires were available with an average of ten respondents from each hotel. The sixty were representing fifteen percent of the total employees in the six selected hotel establishments.

The study was done in 2012. Researchers approached organisations and sought authority from management of the hotels. Meetings were called where the essence of the study was highlighted and ethical issues about the study addressed. Questionnaires were distributed to fifteen conveniently selected and interested staff members from various departments within the hotel who had to take them and fill them in at their own convenience. The filled questionnaires were put in envelopes and sealed before being handed over to the Human Resources Manager from which the Researchers collected from after four working days. The data was later analysed thematically after all the questionnaires were collected (Brouder, 2012, Quinn Patton, 2002). Using manual coding emerging themes were identified, presented and discussed below.

The study showed a major limitation in being based on city hotels in Harare only. Whilst hospitality establishments share a lot, by virtue of location city and resort hotels are affected differently by external forces. However the objective of this study was to explore employee perceptions of HIV \& AIDS on the hospitality industry in Zimbabwe which anyone in the hos- 
pitality industry can give. Future studies can be done to see if the understanding is different among resort hotels to those of city hotels.

The names of the establishments are not mentioned to protect their anonymity and that of its employees who participated in the study. Harare is the largest city and capital of Zimbabwe. It has an estimated population of 1, 6 million. Administratively, Harare is an independent city equivalent to a province covering about $960.6 \mathrm{~km}^{2}$. It is host to one five star hotel, two four star hotels and a number of hotels and lodges with three star and lower rating. There are also a number of tourist attractions such as National Heroes Acre, National Gallery of Zimbabwe, Chapungu Sculpture Park, Zimbabwe Museum of Human Sciences, Mukuvisi Woodlands, Mbizi Game Park and Harare Gardens among others.

\section{Results}

The results of the study showed two main themes that relate to HIV/AIDS and the hospitality industry. The two themes are firstly HIV \& AIDS was being treated as a taboo subject in hospitality organizations and secondly that there are no clear organizational policies on HIV \& AIDS. Respondents direct statements are presented to exemplify their real feelings. However it was the total analysis of the responses that was used to come up with the two themes which represent the strongest themes relating to the phenomenon under investigation in Harare.

\section{HIV \& AIDS a taboo subject}

From the various responses the researchers observed a strong theme indicating that HIV/AIDS was treated as a taboo subject within hospitality organisations. The following are some outstanding statements that were quoted; Employee 32 "no one wants to talk about it" that is HIV/ AIDS. According to employee 15 "there are forced resignations and forced early retirements of affected people due to discrimination tendencies". The employees also indicated that when employees die of HIV/AIDS, the death is attributed to cancer, tuberculosis, diabetes and witchcraft without anyone talking about HIV/AIDS.

\section{No clear organizational policies on HIV \& AIDS}

It was interesting to observe that employees from the hospitality organisations studied seem to agree that there are no clear organisational policies on HIV/AIDS in their organisations. Such comments like by employee 10 who said "there are no budget allocations for HIV/AIDS activities in organisations". Other employees were worried that testing for HIV/AIDS was not covered as essential on recruitment of employees. Employee 45 talked of "lack of database of people living with HIV/AIDS in organisations". As general summary employees were of the view that HIV/AIDS policies are treated by organisations as optional hence they are not taken serious yet HIV/AIDS is a serious issue that deserves maximum attention and urgent reaction. 


\section{Discussion}

\section{HIV \& AIDS a taboo subject}

Taboos are also referred to as avoidance rules (Chigidi, 2009). According to Chigidi (2009) taboos are instruments of socialization and social control. By treating HIV/AIDS as a taboo subject, Zimbabwean hospitality organisations represented by their management are reflecting an inherent nature of Zimbabwean people who perceive issues associated with sex as issues not to talk about anywhere anytime (Chigidi, 2009; Kimberly \& Marquez, 2005; Bozongwana, 1983).

Quoting employee 32 "no one wants to talk about it". This may mean a lot. Firstly it can be a sign of frustration on the part of employees who feel the need to discuss this issue but there was no one willing to talk about it. This kind of behaviour is synonymous with taboos (Gelfand, 1979). It is one of the perceived consequences of not obeying taboos and as such the general people will leave the culprit to deal with his/her problems because they did not obey the values of the society. Silence on HIV issues may also mean lack of understanding, fear, shame or lack of confidence to talk about such issues (Chikovore, et al, 2013). The unwillingness of people and particularly organisations to talk about HIV/AIDS may signal the need to have HIV specialists in organisations to deal with such issues. As a result the fight against HIV/AIDS was treated as the last option on organisations' priorities. This was not proper for the successful fight against this epidemic.

On treating HIV as taboo subject, employee 15 talked of forced resignations and early retirements. This result reinforces results of earlier study by Monjok (2009) carried out in Nigeria. Thus this kind of behaviour is common among Africans as they do not want to be associated with something they consider bad and against societal values. Organisations may be running away from the costs associated with keeping ill health employee and having him or her dying whilst serving them. This was because the associated costs are seen as too many and too much (Welbourn, 2008; Moore et al, 2006). Zimbabwean law is explicitly against discrimination tendencies on the basis of HIV/AIDS, however by having someone raising the issue it confirms its existence. Thus Zimbabwe's hospitality organisations are failing on social cooperate responsibility which is key to the triple bottom line organisational performance measurement, (Fauzi et al, 2010). According to Zengeni and Zengeni (2012) infected employees are transferred to the back office. By forcing resignations, retirements and transfers organisations will be infringing on employee fundamental rights at work with respect to discrimination and stigmatization aimed at workers and people living with or affected by HIV/AIDS (ILO, 2012).

The third subtheme on treatment of HIV/AIDS as taboo subject was exemplified by attributing deaths caused by HIV/AIDS to cancer, tuberculosis, diabetes and witchcraft (Rodlach, 2006; Grange et al, 2010; Bonnet et al, 2009). This continued denial of the existence and devastating effects of HIV/AIDS makes organisations less responsible hence giving them room to turn a blind eye to the epidemic. Thus treating HIV as taboo means more time being wasted watching instead of acting on management, treatment and reducing the spread of the disease so as to reduce its effects on the organisational performance.

\section{No clear organizational policies on HIV \& AIDS}

Wies (1994) defined policies as a set of rules. Organisations have many varied policies on various issues such as human resources, finance, and communication among others. These policies govern behaviour when dealing with issues covered by the policy as they are deemed 
critical and calls for consistent handling of issues covered by the policy. Employees in the hospitality organisations looked at brought out concerns on non availability of clear organisational policies on HIV/AIDS.

Employee 10 said "there are no budget allocations for HIV/AIDS activities in organisations". This can mean a lot. Firstly whatever the organisation does in the course of the year in line with HIV and AIDs becomes an unbudgeted expense which will be viewed as taking profits from the investors. This was not proper as it causes conflicts between investors (employers) and employees who benefits from the HIV/AIDS programmes. Secondly if there was any money put into HIV/AIDS programmes, it was kept at the barest possible. As a consequence the magnitude of activities was minimal and hence the results if any are insignificant with little effects on reducing the effects of HIV/AIDS on the employees and organisations at large. Thirdly it was a silent cry from the employees who are suffering from HIV/ AIDS on what they are getting from their organisations against what they expect considering that HIV/AIDS is an international disaster. By budgeting for HIV/AIDS activities organisations will be able to take on board various programmes from Non Governmental Organisations and Governments that are rolled out during the financial year. This aligns their efforts to those of the nations thus making their voices heard and make bigger impact in the fighting the epidemic.

Other employees were worried that testing for HIV/AIDS was not covered as essential on recruitment of employees. Whilst the Zimbabwean Laws protect employees against discrimination based on HIV/AIDS status, the worries by employees may mean a lot. Socially it may mean that if organisations recruit them knowing their HIV status then they will not have problems with them in future when the HIV start taking a toll on their health. Psychologically it will save them a lot of embarrassment in future trying to explain why they do what they do like being ill for long periods with illnesses that others would shake off in a few days. Economically the organisation would be prepared for the various costs associated with having an HIV positive employee. Thus in the event of serious illness or death they would be prepared and hence will not suffer much from the human resource loss due to HIV/AIDS.

Employee 45 talked of "lack of database of people living with HIV/AIDS in organisations". This situation forces organisations to be reactionary than being proactive. They can put in place staff developmental programmes such as job enlargement, job enrichment and job rotation to prepare other staff to take over in the event of illness and or death. This approach is in line with proactive human resource management despite the health of the employees (Morgeson et al, 2012: 441). Thus the non availability of policy on HIV puts pressure on the organisations and employees, a situation that employees felt could have been better managed if a database of employees living with HIV was there.

\section{Conclusions and Insights}

The objective of the study was to explore employee perceptions of HIV \& AIDS on the hospitality industry in Zimbabwe. The results of the study indicate that HIV/AIDS was a serious issue that was being treated as a taboo subject in hospitality industry and that there are no clear policies on this phenomenon despite its impact on workers, families, organizations, nations and the human race. In conclusion the researchers noted that HIV/AIDS was not being taken seriously in the Zimbabwean hospitality industry. The following three recommendations were made from the study. Firstly, hospitality establishments should embrace the fact that HIV \& 
AIDS exist. Secondly, organizations should work with employees to produce workable policies and thirdly, organizations should take heed of government and NGO's efforts in tackling HIV \& AIDS and do their part in this international cause.

\section{References}

Abbort, G, 2005. Aids Brief for Sectional Planners and Managers. Tourism Sector. Sage Publications.

Apostolipoulos, Y., Leivadi, S \& Yiannakis, A, 1996. The Sociology of Tourism Theoretical and empirical investigation, London. UK.

Archer, L, 2002. Business for Social responsibility HIV/AIDS in the Workplace. Pearson. New Delhi

Arnafi, J., K., Appiah, E., N, \& Awusabo-Asare, K, 2007. Livelihood and the risk of HIV/AIDS infection in Ghana: The case of female itinerant traders. Health Transition Review 7 (Supplement), 225-42.

Beharie, P.P. (Milla). 2010. The Role of Knowledge of HIV/AIDS amongst Employees in a NonGovernmental Organization, Unpublished Mphil Dissertation. University of Stellenbosch, South Africa

Bonnet, F., Burty, C., Lewden,C., Costagliola, D., May, T., Bouteloup, V., Rosenthal, E., Jougla, E., Cacoub, P., Salmon, D., Che^ ne, G, \& Morlat, P, 2008. Changes in Cancer Mortality among HIV-Infected Patients: The Mortalite' 2005 Survey. Clinical Infectious Diseases 48(5), 633-39.

Bozongwana, W, 1983. Ndebele Religion and Customs. Mambo Press. Gweru.

Brungard, R. 1999. HIV \& AIDS in the Workplace: Do Future Hospitality Mangers Have Adequate Education in the Practice of Graduate Research in Hospitality and Tourism. Edited by Chon, K.S. Routledge Publications. New York. USA.

Chigidi, W., L, 2009. Shona Taboos: The Language of Manufacturing Fears for Sustainable Development. The Journal of Pan African Studies 3(1), 179-88.

Chikovore, J., Nystrom, L., Lindmark, G, \& Ahlberg, B. M, 2013. How Can I Gain Skills if I Don't Practice?. The Dynamics of Prohibitive Silence against Pre-Marital Pregnancy and Sex in Zimbabwe 8(1): e53058. doi:10.1371/journal.pone.0053058

Chris, T, 2008. Work Against Aids. Oxford. New York.

Dossier, P, 2007. Business in a world of Aids. McGraw Hill, New York.

Fauzi, H., Svensson, G, \& Rahman, A. A, 2010. Triple Bottom Line as Sustainable Corporate Performance: A Proposition for the Future. Sustainability 2(5), 1345-60.

Ford, N, 1991. Sex on Holiday, The HIV - related Sexual Interaction of Young Tourist Visiting Turban, University of Exter.

Gelfand, M, 1979. Growing Up in Shona Society, Mambo Press. Gweru.

Grange, J., Adhikari, M., Ahmed, Y., Mwaba, P., Dheda, K., Hoelscher, M, \& Zumla, A, 2010. Tuberculosis in association with HIV/AIDS emerges as a major nonobstetric cause of maternal mortality in Sub-Saharan Africa. International Journal of Gynaecology \& Obstetrics $108(3), 181-83$.

Grodeck, B, 2007. HIV and AIDS. Avalon. New York.

Hannum, A.B. 2004. Tricks of the Trade: Sex Tourism in Latin America. Retrieved on 12March 2013 from Available at http://www.fas. harvard. edu/\%7Edrclas/publications/revista/Tourism 
International Labour Organisation, 2012. HIV and AIDS: Guide for the tourism sector. International Labour Office Sectoral Activities Department and ILO Programme on HIV and AIDS and the World of Work. - Geneva.

International Labour Organisation, 2011. Employment in the tourism industry to grow significantly, International Labour Organisation, accessed from http://www.ilo.org/global/publications/magazines-and-journals on 26 February 2013.

ILO, 2011. An ILO code of practice on HIV/AIDS and the world of work. International Issues.

Jackson, H, 2002. AIDS Africa: Continent in Crisis, Frontline Publishing. Zimbabwe.

Jennifer, H, 2004. HIV: The Culture of Silence must be overcome. Pearson. New York.

Kimberly, AMR, \& Marquez, J, 2005. Experiences of HIV/AIDS Counselors in Zimbabwe and Their Perceptions on the State of HIV/AIDS Counseling in Zimbabwe. International Journal for the Advancement of Counseling 27(3), 413-29

Lawson, L, 2004. Living Proof Community Action on AIDS. Pearson. USA.

Loewenson, R, 2004. Best practices: company actions on HIV/AIDS in Southern Africa. London

Matthew, HTY, \& Ineson, EM, 2009. HIV-infected employees in the Asian hospitality industry. Journal of Service Management 20(5), 503-20.

Matthew HTY, \& Ineson, EM, 2012. Diversity management: The treatment of HIV-positive employees. AIDS Care: Psychological and Socio-medical Aspects of AIDS/HIV 24(11), 1349-58.

Mayorga, R, 2001/2. Sexual Exchange. SAFAIDS. Harare.

Monjok, E., Smesny, A, \& Essien, EJ, 2009. HIV/AIDS - Related Stigma and Discrimination in Nigeria: Review of Research Studies and future directions for Prevention Strategies. African Journal of Reproductive Health 13(3), 21-35.

Moore, M., and Frost, M, 2006. Business Partners: A multiple stakeholder response. Praeger Publications, USA

Morgeson, FP., Campion, MA, \& Bruning, PF, 2012. Job and Team Design in Handbook of Human Factors and Ergonomics, $4^{\text {th }}$ Ed, Edited by Salvendy, G., John Wiley \& Sons, New Jersey.

Oppong, C, 1995. A High Price to pay: for education, subsistence or a place in the job. Health Transition Review 5 (Supplement), 35-56.

Ruggles, E., Fantan, T., McPherson, M \& Whiteside, A, 2001. The Economic Impact of HIV and AIDS. Pearson Education. New York.

Sirvastava, G \& Sirvastava, A, 2003. Aids Pathology Diagnosis, Treatment and Prevention, $2^{\text {nd }}$ Ed. CBS. New Delhi.

UNAIDS. 2005. Putting HIV/AIDS on the Business Agenda. UNAIDS. Geneva

UNAIDS, 2009. AIDS epidemic update. UNAIDS. WHO.

UNAIDS, 2010. HIV/AIDS and the Workplace - forging innovative business responses. UNAIDS Technical Update (UNAIDS Best Practice Collection: Technical Update). UNAIDS.

UNICEF, WHO and Ministry of ascending Health, 2011. Insights and Foresights. UNICEF, Harare.

Welbourn, A \& Hoare, J, 2008. HIV and AIDS. Oxfarm GB. Oxford.

WHO 2007. Global HIV prevalence has levelled off, World Health Organization, accessed from http://www.who.int/mediacentre/news/releases/2007/pr61/en/index.html. on 27 February 2013.

Wolfensohn, D, 2009. Aids Education, Praeger Publications, USA.

Zengeni, DMF, \& Zengeni, N. 2012. Impact of HIV/AIDS to the Tourism Sector Human Resources: Case of Selected hotels in Harare. International Journal of Development and sustainability 1(3), (In Press) 